\title{
Students' university aspirations and attainment grouping in secondary schools
}

Anna Mazenod, Jeremy Hodgen, Becky Francis, Becky Taylor and Antonina Tereshchenko

\section{Author list}

1. Anna Mazenod (corresponding author) a.mazenod@ucl.ac.uk

2. Jeremy Hodgen j.hodgen@ucl.ac.uk

3. Becky Francis b.francis@ucl.ac.uk

4. Becky Taylor becky.taylor@ucl.ac.uk

5. Antonina Tereshchenko a.tereshchenko@ucl.ac.uk

Department of Education, Practice and Society, UCL Institute of Education, 20 Bedford Way London WC1H 0AL, UK. 02076126000

\section{Acknowledgements}

The authors would like to acknowledge the contribution of the wider Best Practice in Grouping Students team and Dr Richard Sheldrake

\section{Funding details}

This work was supported by a grant from the Education Endowment Foundation.

\section{Disclosure statement}

There are no conflicts of interest relating to the research reported in this article.

\section{Keywords}

University aspirations, capacity to aspire, setting, tracking, student characteristics, social inequality 


\title{
Students' university aspirations and attainment grouping in secondary schools
}

\begin{abstract}
International evidence shows that students from more disadvantaged backgrounds are less likely to attend university. We examine the potential link between university aspiration and secondary schools' attainment grouping practices (tracking/setting). Modelling of longitudinal student questionnaires $(\mathrm{N}=6680)$ completed in England suggests that there is a slight cumulative association between students' university aspirations and their set placement. Interestingly we find that student self-confidence predicts university aspirations over and above both prior aspirations and attainment. Our findings suggest that to improve our understanding of students' university aspirations it is crucial to take account of factors other than just prior attainment. The concept of capacity to aspire emphasises the multiplicity of factors involved in enabling or hindering aspirations for university, and their interaction over time. We argue that universities have an important role in realising more socially just patterns in higher education participation through outreach work that can enhance students' capacity to aspire to university.
\end{abstract}

\section{Introduction}

The majority of secondary school students in Western societies such as the UK and US aspire to go to university (Berrington, Roberts and Tammes, 2016; Hartas, 2016; Venezia and Kirst, 2005). Whilst an increasing number of young people now pursue higher education studies (Whitty, Hayton and Tang, 2015), it is clear that many students do not fulfil their earlier university aspirations. International evidence shows that students from advantaged backgrounds are more likely to attend university (Altbach, Reisberg and Rumbley, 2009; McMahon, Harwood and Hickey-Moody, 2016; Tomaszewski, Perales and Xiang, 2015), suggesting that students from more disadvantaged backgrounds are less likely to turn their aspiration into participation (Bowden and Doughney, 2010), although recent studies drawing on longitudinal UK data suggest that the apparent socio-economic patterns in higher education participation can be largely explained by prior attainment as early as at 11 (Anders, 2012). As students' educational outcomes, including measures of student attainment are, however inextricably linked to the social and educational context in which students are schooled (Ball, 2010), it is important to examine students' school trajectories and consider how their experiences of schooling might impact on their aspirations for university (Mangan et al., 2010; Santelices, Horn and Catalan, 2017; Venezia and Kirst, 2005; Whitty, Hayton and Tang, 2015;). Whilst most universities are primarily concerned with measures of educational attainment at the point of student recruitment and admission, students' earlier educational trajectories and their potential impact on university aspirations and their realisation are of 
crucial importance in addressing the socially inequitable patterns in higher education participation in the UK and internationally.

In this article we focus on secondary school students' university aspirations, and whether these are affected by attainment grouping. Our ongoing project on grouping practices in English secondary schools has generated a longitudinal dataset ( $\mathrm{N}=6680$ students) that uniquely enables us to test the potential relationship between grouping practices and students' university aspirations. The project investigates how secondary school students are grouped for their learning in English and mathematics with a particular focus on the efficacy of different grouping approaches on improving the attainment of students from disadvantaged backgrounds. Given our extensive dataset we are able to extend the examination of students' university aspirations to include factors such as self-confidence and student liking for school, that have not been included in prior research on students' university aspirations. We begin by outlining how attainment grouping practices might influence secondary school students' aspirations for university and how we theorise students' capacity to aspire. The second substantive part of the paper provides details on the methodology of the study. This is followed by a presentation and a discussion of our findings where we argue for an active role for universities through outreach work in schools and communities in order to realise more socially just patterns in higher education participation.

\section{How might attainment grouping practices influence aspirations for university?}

Attainment grouping practices tend to be referred to as tracking in the US literature and setting or streaming in the UK literature (see e.g. Oakes, 2005; Francis et al., 2017a). Setting, whereby students are allocated to a group (a set) depending on their prior attainment is a prevalent practice in English secondary schools, especially for mathematics (OECD, 2013). This is despite research continuing to document the potentially negative aspects of setting on the outcomes of students in low attainment groups (Francis et al., 2017a; Oakes, 2005; Parsons and Hallam, 2014), and particularly on their assessment of themselves as successful learners (Francis et al., 2017b; Gillborn and Youdell, 2000; Hart et al., 2004). Alternative grouping practices, such as grouping students into mixed attainment classes are less common for subjects such as mathematics (Taylor et al., 2016). 
Reviewing prior research on attainment grouping it seems that the practice of grouping students into sets could be contributing to 'tiering' of aspirations with students' aspirations being related to their placement in the attainment group hierarchy through two interrelated factors: curriculum, and the labelling communicated by the practice of tracking/setting. A classic example of the consequences of a differentiated curriculum is presented by Gilborn and Youdell (2000) who carefully document the impact of educational triage on students' educational pathways with differentiated curricula and pathway associated learner identities. The tiering of GCSE exam papers in mathematics in English secondary schools remains a very tangible way in which different curricula are set for different groups of students with potentially aspiration constraining outcomes for young people that they may not themselves be aware of (Boaler, Wiliam and Brown, 2000). Performance in mathematics can for example route students either down an academic or a vocational pathway (Dalby, 2016). In the US context Venezia and Kirst (2005) have also importantly identified the impact of differentiated curricula (e.g. access to college preparation courses) between high school tracks can shape students' educational aspirations.

The day-to-day practices and experiences of tracking or setting in themselves can also be seen to impact on students' aspirations through students' internalisation of their track or set position (Berends, 1995; Lehmann, 2009). This can be understood as a kind of habitus construction, the learned dispositions that shape students' understanding of the possibilities for their future (Ball et al., 2002), wherein a self-fulfilling prophesy may impact students' self-perception and confidence in learning (Francis et al., 2017b; Lehmann, 2009). The differential aspirations associated with the different pathways may go unchallenged and indeed be indirectly encouraged by teachers (Furlong, 2005). This is not inconsequential as we know that decisions relating to attainment group placement are not always made on attainment data alone (Dunne et al., 2007; Taylor et al., 2018) and that students from disadvantaged backgrounds are overrepresented in low attainment groups (Dunne et al, 2007; Kutnick et al., 2005; Archer et al., 2018). These group placement decisions have an impact on and interact with the learner habitus the young people develop to produce different kinds of learning trajectory possibilities and pathways, whether actively chosen or drifted into. We will next outline how we draw on the concept of capacity to aspire to university (Bok, 2010; Gale and Parker, 2013; Smith, 2011) in our examination of attainment grouping practices and students' university aspirations.

\section{Theorising capacity to aspire to university}


Lack of aspirations as a straightforward explanation for poor educational outcomes and relatively curtailed educational trajectories has been robustly critiqued by researchers with evidence from a range of educational contexts (Archer, DeWitt and Wong, 2014; Kintrea, St Clair and Houston, 2011; Zipin et al., 2015). As Kintrea, St Clair and Houston (2011, p.8) assert: 'However much the young person wants to be a lawyer, this aspiration is incompatible with leaving school at the age of 16.' Individual aspirations (or their apparent lack of) are thus only one part of the picture. Instead of the deficit-focused idea of a lack of aspiration, Appadurai's (2004) concept of 'capacity to aspire' has been fruitfully applied in recent higher education research (Bok, 2010; Gale and Parker, 2013; Smith, 2011).

The concept of the capacity to aspire emphasises the importance of the individual's surroundings which can over time encourage or hinder the development of aspirations and their realisation (Appadurai, 2004). The concept of the capacity to aspire encourages us to consider individuals' agency as being constrained by collectively experienced factors relating to, for example local culture and physical environment, but that is also open to change at the collective or the individual level. As a future-oriented concept, it is well suited to analysing secondary school students' university aspirations at a point in their life when university may be only vaguely imagined, and it enables us to reflect on why and how some young people's aspirations are realised whereas for others, aspirations become unattainable or are self-moderated over time (Bok, 2010).

This developmental perspective is important as empirical research has identified prior attainment as the key factor contributing to students' university aspirations (Anders, 2012; Chowdry et al., 2010) with gender (Berrington, Roberts and Tammes, 2016; Gale and Parker, 2015; Hartas, 2016), parental education and cultural capital or parental involvement also being associated with students' university aspirations (Davies, Qiu and Davies, 2014; Perna and Titus, 2005), and socio-economic background moderating these aspirations over time (Anders, 2017). Research has also importantly drawn attention to the 'gendered, classed and/or racialized patterns in young people's aspirations' (Archer, DeWitt and Wong, 2014, p.59). These prior studies show that there are considerable differences in young people's horizons of aspirations with those from more advantaged backgrounds tending to view higher education as a near compulsory phase of education (Ball et al., 2002), and those from more disadvantaged backgrounds being more likely to view university as 'unthinkable' (Archer, Hollingworth and Halsall, 2007). However, whilst an association between individual aspirations and attainment 
has been demonstrated, the causal relationships between aspirations and attainment are poorly understood (Gorard, See and Davies, 2012).

An understanding of the capacity to aspire to university as something that is developed over time thus needs to take account of the student's experiences in school, as well as their home environment which can shape the individual's understanding or belief in himself/herself as either someone who will, as someone who might; or as someone who definitely will not go to university. In our examination of students' aspirations for university by their placement in the attainment group hierarchy, we have thus extended our analysis beyond the variables relating to prior attainment, student characteristics (gender, ethnicity and socio-economic background) and cultural capital used in the prior research on students' university aspirations already referred to in order to control for at least some elements of the student experiences or attitudes in school. Prior longitudinal research on university participation has importantly found an association between positive school experiences and university participation (Tomaszewski, Perales and Xiang, 2017).

Using the measures developed and adapted for our present study, we have controlled for a measure of student general self-confidence in learning and a measure of student liking for school (for full discussion of the self-confidence measure see Francis et al., 2017b; Mazenod et al. (forthcoming) for student liking for school). It should be noted that our conceptualisation of self-confidence and the measure of student general self-confidence (as distinct from subjectspecific self-confidence) differs from, for example the approach used in Gorard, See and Davies' (2012) extensive review of research that found no evidence of a causal relationship between student self-concept or self-esteem and participation in post-compulsory education. We have also used a broad definition of cultural capital and operationalised the parental education variable as a measure of cultural capital given the relevance of prior family knowledge and experience of higher education in shaping students' understanding of and aspirations for university (Archer, DeWitt and Wong, 2013; Ball et al., 2002). Details on our wider study, the student questionnaire and the specific variables used in our analysis are provided in the next section on methodology.

\section{Methodology}

Data 
The wider study underpinning the data presented in this paper is a mixed methods study of grouping practices and their impact on student outcomes and students' experiences of secondary schooling in England funded by Education Endowment Foundation. Two randomised controlled trials: 'Best Practice in Setting' and 'Best Practice in Mixed Attainment' were run as part of the study alongside further data being gathered through student and teacher questionnaires, teacher interviews and student focus groups (see Francis et al, 2017a for background to the study). The trials focused on teaching and learning in English and mathematics because these subjects have tended to be viewed as the key school subjects in England, but also because there is diversity in the content and pedagogy across these subjects. The data presented in this paper is drawn from student questionnaires completed by students in schools participating in the 'Best Practice in Setting' trial. A total of 126 schools that group students by attainment for English and/or mathematics participated in 'Best Practice in Setting' with 75 schools setting students for both English and mathematics, 6 for English only and 45 for mathematics only. A mixture of volunteer and randomised sampling was used to recruit the schools and the overall sample of 126 schools represents a good variety of urban and rural areas (for details on recruitment and sampling process followed see Taylor et al., 2016).

As part of the project all students from the 126 schools were asked to complete the student questionnaire in the autumn term 2015 when they were starting Year 7, and again in the summer term 2017 as they were finishing their Year $8^{1}$. Schools were responsible for administering the questionnaires to the relevant groups of students with questionnaire completion protocols having been specified by the project team. Questionnaires at both time points were returned from 64 out of the 126 study schools, resulting in an overall school response rate of $51 \%$. In this paper, we focus on analysing student questionnaire data from students who completed questionnaires at both times (schools participating in study in mathematics $\mathrm{N}=4408$ students; schools participating in English $\mathrm{N}=1972$ students). The questionnaire included items asking students to indicate their group placement for English and mathematics and to respond to questions relating to their liking for school and their general self-confidence, as well as questions relating to their socio-demographic background (ethnicity, parental education and occupation). Prior to the launch of the questionnaire, it was extensively piloted with Year 7 students in schools not included in the study sample, and the reliability and validity of the

\footnotetext{
${ }^{1}$ Year 7 students are aged 11-12; Year 8 students 12-13
} 
questionnaire items was enhanced for example by amending wording of the questions that had been commonly misunderstood by students completing the pilot questionnaires.

Questionnaire completion was undertaken online at the study schools during normal school hours. The questionnaire took approximately half an hour to complete. To enhance the data set, additional data from National Pupil Database (NPD) was matched with the questionnaire responses for students whose parents had consented to the use of the data. This additional data consisted of information on students' prior attainment in English (reading) and mathematics, and their status of being, or having been in receipt of free school meal (FSM), a measure of low socio-economic status. Data was initially matched for $100 \%$ matches based on students' first name, last name and date of birth, and this process was followed by fuzzy matching and manual matching where necessary. We will next describe the variables used in our analysis.

\section{Variables}

University aspirations Students' university aspirations were measured through questionnaire item 'Do you expect to go to university?' with response-categories of (1) 'No, definitely not', (2) No, unlikely', (3) 'Maybe', (4) 'Yes, quite likely', and (5) 'Yes, definitely'.

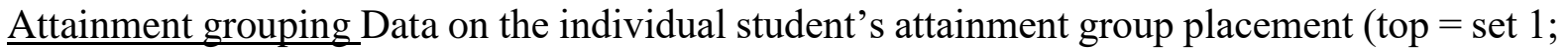
middle $=$ all sets between the top and bottom sets; bottom $=$ the lowest set $)$ was captured through the student questionnaire.

Prior attainment Data on students' prior attainment (Key Stage 2 reading and mathematics test at the end of Key Stage $2^{2}$ results broken down for high/medium/low tertiles) was matched from NPD.

Student characteristics Data on students' gender (Male/Female), ethnicity (White/Asian/Black/Mixed); English as an additional language (EAL) (based on student selfreported first language) and parental occupation (higher; intermediate; lower) was gathered through the questionnaire. Data on student (FSM) status (EVERFSM_ALL) was matched from NPD.

\footnotetext{
${ }^{2}$ Phase of education when pupils are aged 7-11
} 
Liking for school Data on student liking for school was measured through students responding to various statements in the questionnaire via responses categories of (1) 'strongly disagree', (2) 'disagree', (3) 'neither agree nor disagree', (4) 'agree', and (5) 'strongly agree'. For responses to negatively-orientated items (e.g. 'Most of the time I don't want to go to school'), the responses-categories were reversed (i.e. from (5) 'strongly disagree' to (1) 'strongly agree') for the analysis. Higher response scores therefore consistently reflected more positive views (i.e. agreeing with positive statements and disagreeing with negative statements). The relevant items were aggregated into a theorised scale for 'liking for school,' which showed acceptable indicators of reliability ( 6 items, e.g. 'I am very happy at this school' and 'I enjoy nearly all subjects at school'; Cronbach's alpha $=0.818$ at Year 7 for schools participating in mathematics, correspondingly 0.820 at Year 7 for schools participating in English).

General self-confidence in learning Data on general self-confidence in learning was also measured through five-category Likert scales and relevant items aggregated into a theorised scale 'general self-confidence in learning ( 7 items, e.g. 'I learn quickly' and 'I am generally high achieving in my studies'; Cronbach's alpha $=0.827$ at Year 7 for schools participating in mathematics, correspondingly 0.831 at Year 7 for schools participating in English).

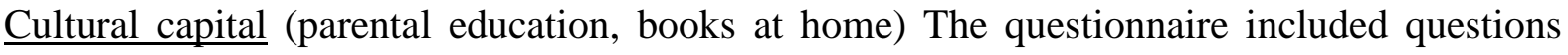
about parental education (left at or before 16; further education; university) and number of books at home (none/very few/about one shelf filled with books/one bookcase filled with books/more than one bookcase filled with books).

\section{Findings}

Only a minority of students in our sample seemed to reject university outright. Tables 1 and 2 show differences across the groups of students through analysis of variance (ANOVA), with a mean of 4 for groups of students for sets in mathematics (Table 1) and 3.94 for groups of students for sets in English (Table 2). Students on average thus expected that they would go to university. Our finding that the majority of students hold firm or tentative aspirations to go to university at this age replicates earlier research findings (Berrington, Roberts and Tammes, 2016; Hartas, 2016).

Table 1 - Overall group comparison by sets in mathematics via analysis of variance (ANOVA) Table 2 - Overall group comparison by sets in English via analysis of variance (ANOVA) 
$\underline{\text { Table } 1 \text { Overall group comparison by sets in mathematics via analysis of variance (ANOVA) }}{ }^{3}$

\begin{tabular}{|c|c|c|c|c|c|c|c|c|c|c|}
\hline \multirow[b]{3}{*}{ Indicator (scale) } & \multirow{2}{*}{\multicolumn{2}{|c|}{ All }} & \multicolumn{8}{|c|}{ Y7 Self-reported set } \\
\hline & & & \multicolumn{2}{|c|}{ Top set } & \multicolumn{2}{|c|}{ Middle sets } & \multicolumn{2}{|c|}{ Bottom set } & \multicolumn{2}{|c|}{ Difference } \\
\hline & $\mathrm{M}$ & SD & $\mathrm{M}$ & $\mathrm{SD}$ & $\mathrm{M}$ & SD & M & SD & $\mathrm{R}^{2}$ & $\begin{array}{l}\text { Sig. } \\
\text { (p) }\end{array}$ \\
\hline Gender (1=boy) & .51 & .50 & .57 & .50 & .48 & .50 & .47 & .50 & .008 & $<.001$ \\
\hline $\begin{array}{l}\text { Ethnicity: White } \\
(1=Y)\end{array}$ & .80 & .40 & .78 & .42 & .81 & .39 & .82 & .39 & .001 & .047 \\
\hline $\begin{array}{l}\text { Ethnicity: Asian } \\
(1=Y)\end{array}$ & .07 & .26 & .09 & .28 & .06 & .24 & .06 & .23 & .003 & .002 \\
\hline $\begin{array}{l}\text { Ethnicity: Black } \\
(1=Y)\end{array}$ & .04 & .18 & .03 & .17 & .04 & .19 & .06 & .23 & .001 & .113 \\
\hline $\begin{array}{l}\text { Ethnicity: Mixed } \\
(1=Y)\end{array}$ & .07 & .25 & .07 & .25 & .07 & .26 & .06 & .23 & .000 & .598 \\
\hline $\begin{array}{l}\text { Ethnicity: Other } \\
(1=Y)\end{array}$ & .03 & .16 & .03 & .18 & .02 & .15 & .02 & .13 & .001 & .111 \\
\hline $\operatorname{EAL}(1=\mathrm{Y})$ & .08 & .27 & .09 & .28 & .07 & .26 & .09 & .29 & .001 & .212 \\
\hline Books at home (1-5) & 4.19 & 1.00 & 4.34 & .93 & 4.14 & 1.01 & 3.69 & 1.16 & .026 & $<.001$ \\
\hline $\begin{array}{l}\text { Highest parental } \\
\text { education }(1-4)\end{array}$ & 3.25 & .87 & 3.35 & .84 & 3.21 & .87 & 2.97 & .91 & .013 & $<.001$ \\
\hline $\begin{array}{l}\text { Highest parental } \\
\text { occupation (1-7) }\end{array}$ & 5.16 & 1.79 & 5.40 & 1.70 & 5.03 & 1.82 & 4.62 & 1.87 & .016 & $<.001$ \\
\hline $\operatorname{FSM}(1=\mathrm{Y})$ & .19 & .39 & .16 & .37 & .21 & .40 & .23 & .42 & .003 & .001 \\
\hline $\begin{array}{l}\text { KS2 Mathematics } \\
\text { fine score }(1-5)\end{array}$ & 3.65 & .74 & 4.20 & .61 & 3.36 & .50 & 2.69 & .66 & .419 & $<.001$ \\
\hline $\begin{array}{l}\text { Y7: University } \\
\text { aspirations (1-5) }\end{array}$ & 4.00 & .94 & 4.17 & .88 & 3.92 & .95 & 3.63 & 1.08 & .027 & $<.001$ \\
\hline $\begin{array}{l}\text { Y8: University } \\
\text { aspirations (1-5) }\end{array}$ & 3.91 & 1.02 & 4.12 & .93 & 3.81 & 1.06 & 3.50 & 1.09 & .032 & $<.001$ \\
\hline $\begin{array}{l}\text { Change in university } \\
\text { aspirations }\end{array}$ & -.07 & .97 & -.05 & .89 & -.09 & 1.01 & -.11 & 1.12 & .001 & .303 \\
\hline $\begin{array}{l}\text { Y7: Liking for school } \\
(1-5)\end{array}$ & 4.39 & .60 & 4.42 & .58 & 4.38 & .61 & 4.27 & 70 & .004 & $<.001$ \\
\hline $\begin{array}{l}\text { Y8: Liking for school } \\
(1-5)\end{array}$ & 3.89 & .76 & 3.97 & .75 & 3.85 & .76 & 3.72 & .79 & .009 & $<.001$ \\
\hline $\begin{array}{l}\text { Change in liking for } \\
\text { school }\end{array}$ & -.50 & .73 & -.45 & .69 & -.53 & .75 & -.54 & .83 & .003 & .003 \\
\hline $\begin{array}{l}\text { Y7: General self- } \\
\text { confidence }(1-5)\end{array}$ & 4.28 & .57 & 4.41 & .50 & 4.22 & .58 & 3.97 & .69 & .046 & $<.001$ \\
\hline $\begin{array}{l}\text { Y8: General self- } \\
\text { confidence }(1-5)\end{array}$ & 3.97 & .76 & 4.16 & .71 & 3.88 & .77 & 3.62 & .77 & .046 & $<.001$ \\
\hline $\begin{array}{l}\text { Change in self- } \\
\text { confidence }\end{array}$ & -.31 & .70 & -.25 & .65 & -.34 & .72 & -.36 & .79 & .004 & $<.001$ \\
\hline Number of students & 4408 & & 1773 & & 2345 & & 290 & & & \\
\hline
\end{tabular}

Notes: means (M), standard deviations (SD) are shown; the magnitude $\left(\mathrm{R}^{2}\right)$ and significance (Sig. (p)) of the overall difference across the groups is also shown; significant $\mathrm{p}$-values $(\mathrm{p}<$ $.05)$ are highlighted in bold

\footnotetext{
${ }^{3}$ With a Bonferroni adjustment for multiple testing, all statistically significant differences remain significant except for 'Ethnicity: White' and 'Change in liking for school'
} 
$\underline{\text { Table } 2 \text { Overall group comparison by sets in English via analysis of variance (ANOVA) }}{ }^{4}$

Y7 Self-reported set

\begin{tabular}{|c|c|c|c|c|c|c|c|c|c|c|}
\hline \multirow[b]{3}{*}{ Indicator (scale) } & \multirow{2}{*}{\multicolumn{2}{|c|}{ All }} & \multirow{2}{*}{\multicolumn{2}{|c|}{ Top set }} & \multirow{2}{*}{\multicolumn{2}{|c|}{ Middle sets }} & \multirow{2}{*}{\multicolumn{2}{|c|}{ Bottom set }} & \multirow{2}{*}{\multicolumn{2}{|c|}{ Difference }} \\
\hline & & & & & & & & & & \\
\hline & $\mathrm{M}$ & SD & $\mathrm{M}$ & SD & M & SD & M & SD & $\mathrm{R}^{2}$ & $\begin{array}{l}\text { Sig. } \\
\text { (p) }\end{array}$ \\
\hline Gender (1=boy) & .53 & .50 & .48 & .50 & .55 & .50 & .58 & .50 & .005 & .009 \\
\hline $\begin{array}{l}\text { Ethnicity: White } \\
(1=Y)\end{array}$ & .82 & .38 & .85 & .36 & .80 & .40 & .85 & .35 & .004 & .021 \\
\hline $\begin{array}{l}\text { Ethnicity: Asian } \\
(1=Y)\end{array}$ & .06 & .23 & .04 & .20 & .07 & .25 & .03 & .17 & .004 & .030 \\
\hline $\begin{array}{l}\text { Ethnicity: Black } \\
(1=\mathrm{Y})\end{array}$ & .02 & .15 & .03 & .16 & .02 & .15 & .01 & .10 & .000 & .626 \\
\hline $\begin{array}{l}\text { Ethnicity: Mixed } \\
(1=Y)\end{array}$ & .07 & .25 & .06 & .24 & .08 & .26 & .05 & .22 & .001 & .442 \\
\hline $\begin{array}{l}\text { Ethnicity: Other } \\
(1=Y)\end{array}$ & .03 & .17 & .02 & .14 & .03 & .18 & .05 & .22 & .002 & .144 \\
\hline EAL $(1=Y)$ & .06 & .24 & .05 & .22 & .08 & .26 & .05 & .22 & .003 & .067 \\
\hline Books at home (1-5) & 4.13 & 1.03 & 4.38 & .90 & 3.98 & 1.06 & 3.75 & 1.28 & .041 & $<.001$ \\
\hline $\begin{array}{l}\text { Highest parental } \\
\text { education (1-4) }\end{array}$ & 3.14 & .88 & 3.20 & .88 & 3.11 & .87 & 2.92 & .99 & .005 & .008 \\
\hline $\begin{array}{l}\text { Highest parental } \\
\text { occupation }(1-7)\end{array}$ & 4.97 & 1.83 & 5.20 & 1.78 & 4.84 & 1.84 & 4.43 & 1.99 & .013 & $<.001$ \\
\hline FSM $(1=Y)$ & .22 & .42 & .20 & .40 & .24 & .43 & .25 & .44 & .003 & .057 \\
\hline $\begin{array}{l}\text { KS2 Reading fine } \\
\text { score }(1-5)\end{array}$ & 3.53 & .51 & 3.82 & .30 & 3.38 & .46 & 2.76 & .77 & .295 & $<.001$ \\
\hline $\begin{array}{l}\text { Y7: University } \\
\text { aspirations (1-5) }\end{array}$ & 3.94 & .97 & 4.09 & .94 & 3.86 & .96 & 3.55 & 1.22 & .021 & $<.001$ \\
\hline $\begin{array}{l}\text { Y8: University } \\
\text { aspirations (1-5) }\end{array}$ & 3.86 & 1.04 & 4.06 & .98 & 3.76 & 1.04 & 3.32 & 1.24 & .032 & $<.001$ \\
\hline $\begin{array}{l}\text { Change in university } \\
\text { aspirations }\end{array}$ & -.07 & 1.00 & -.02 & .96 & -.09 & 1.01 & -.25 & 1.29 & .003 & .106 \\
\hline $\begin{array}{l}\text { Y7: Liking for school } \\
(1-5)\end{array}$ & 4.37 & .63 & 4.42 & .59 & 4.34 & .65 & 4.29 & .73 & .004 & .014 \\
\hline $\begin{array}{l}\text { Y8: Liking for school } \\
(1-5)\end{array}$ & 3.87 & .76 & 3.96 & .73 & 3.81 & .78 & 3.73 & .79 & .011 & $<.001$ \\
\hline $\begin{array}{l}\text { Change in liking for } \\
\text { school }\end{array}$ & -.51 & .76 & -.46 & .71 & -.54 & .80 & -.57 & .83 & .003 & .075 \\
\hline $\begin{array}{l}\text { Y7: General self- } \\
\text { confidence }(1-5)\end{array}$ & 4.25 & .60 & 4.40 & .54 & 4.17 & .61 & 4.03 & .72 & .040 & $<.001$ \\
\hline $\begin{array}{l}\text { Y8: General self- } \\
\text { confidence }(1-5)\end{array}$ & 3.95 & .78 & 4.09 & .75 & 3.85 & .77 & 3.80 & .86 & .024 & $<.001$ \\
\hline $\begin{array}{l}\text { Change in self- } \\
\text { confidence }\end{array}$ & -.31 & .73 & -.30 & .69 & -.31 & .76 & -.24 & .73 & .001 & .597 \\
\hline Number of students & 1972 & & 794 & & 1082 & & 96 & & & \\
\hline
\end{tabular}

${ }^{4}$ With a Bonferroni adjustment for multiple testing, all statistically significant differences remain significant except for 'Gender', 'Ethnicity: White', 'Ethnicity: Asian', 'Highest Parental Occupation' and 'Y7 Liking for school'. 
Notes: means (M), standard deviations (SD) are shown; the magnitude $\left(\mathrm{R}^{2}\right)$ and significance (Sig. (p)) of the overall difference across the groups is also shown; significant $\mathrm{p}$-values $(\mathrm{p}<$ $.05)$ are highlighted in bold

As tables 1 and 2 show groups of students in the top sets held on average the highest aspirations to go to university. These tables are based on students' self-reported set placement in Year 7 (see supplementary information tables for equivalent tables based on students' self-reported set placement in Year 8). We then predicted students' university aspirations through multilevel linear regression (via maximum-likelihood estimation with variable intercepts per school) to account for students being sampled by / clustered within schools (Snijders \& Bosker, 2012). Predictive models essentially reveal the independent predictive association between each predictor and the outcome, statistically accounting for all of the other predictors. In our presentation of the models we have throughout reported on the statistical significance (pvalues) and the magnitude of the predictive associations (standardised coefficients). These standardised coefficients reflected the number of standard deviations of increase/decrease that would occur in the outcome, given one standard deviation increase in the predictor. We have here consistently reported on observed responses as estimating any missing responses within the constraints of our study design did not appear to notably alter the results.

Analysis of the data collected at the start of our study when students were in Year 7 and shown in tables 3 and 4 below suggests that set placement in Year 7, the first year of secondary school, is not predictive of students' university aspirations when controlling for other variables.

Table 3 - Predicting students' university aspirations (reported as of Year 7) by sets in mathematics

Table 4 - Predicting students' university aspirations (reported as of Year 7) by sets in English 
Table 3 - Predicting students' university aspirations (reported as of Year 7) by sets in mathematics

\begin{tabular}{|c|c|c|c|c|c|c|c|c|c|c|c|c|c|c|}
\hline \multirow{3}{*}{ Predictor } & \multicolumn{2}{|c|}{ Step 1a } & \multicolumn{2}{|c|}{ Step $1 b$} & \multicolumn{2}{|c|}{ Step 2} & \multicolumn{2}{|c|}{ Step 3} & \multicolumn{2}{|c|}{ Step $4 a$} & \multicolumn{2}{|c|}{ Step $4 b$} & \multicolumn{2}{|c|}{ Step 5} \\
\hline & & Sig & & Sig & & Sig & & Sig & & Sig & & Sig & & Sig \\
\hline & Std. B & (p) & Std. B & (p) & Std. B & (p) & Std. B & (p) & Std. B & (p) & Std. B & (p) & Std. B & (p) \\
\hline Constant/intercept & N/A & $<.001$ & N/A & $<.001$ & N/A & $<.001$ & N/A & $<.001$ & N/A & $<.001$ & N/A & $<.001$ & N/A & $<.001$ \\
\hline Y7: Setting: Middle set & & & & & & & & & & & & & & \\
\hline (v. top) & -.134 & $<.001$ & & & -.043 & .037 & -.035 & .092 & -.030 & .139 & -.022 & .262 & -.023 & .250 \\
\hline Y7: Setting: Bottom set & & & & & & & & & & & & & & \\
\hline $\begin{array}{l}\text { (v. top) } \\
\text { KS2 mathematics fine }\end{array}$ & -.134 & $<.001$ & & & -.057 & .004 & -.045 & .025 & -.041 & .043 & -.028 & .160 & -.030 & .121 \\
\hline score & & & .190 & $<.001$ & .151 & $<.001$ & .130 & $<.001$ & .132 & $<.001$ & .089 & $<.001$ & .092 & $<.001$ \\
\hline Gender (1=boy) & & & & & & & -.086 & $<.001$ & -.075 & $<.001$ & -.086 & $<.001$ & -.083 & $<.001$ \\
\hline Ethnicity: Asian $(1=Y)$ & & & & & & & .107 & $<.001$ & .102 & $<.001$ & .103 & $<.001$ & .102 & $<.001$ \\
\hline Ethnicity: Black $(1=Y)$ & & & & & & & .093 & $<.001$ & .095 & $<.001$ & .087 & $<.001$ & .088 & $<.001$ \\
\hline Ethnicity: Mixed $(1=Y)$ & & & & & & & .029 & .059 & .033 & .031 & .027 & .071 & .029 & .056 \\
\hline Ethnicity: Other $(1=\mathrm{Y})$ & & & & & & & .047 & .003 & .052 & .001 & .046 & .003 & .048 & .002 \\
\hline $\operatorname{EAL}(1=\mathrm{Y})$ & & & & & & & .080 & $<.001$ & .077 & $<.001$ & .069 & $<.001$ & .070 & $<.001$ \\
\hline Books at home & & & & & & & .088 & $<.001$ & .067 & $<.001$ & .056 & .001 & .054 & .002 \\
\hline Highest parental & & & & & & & & & & & & & & \\
\hline education & & & & & & & .153 & $<.001$ & .153 & $<.001$ & .145 & $<.001$ & .146 & $<.001$ \\
\hline Highest parental & & & & & & & & & & & & & & \\
\hline occupation & & & & & & & .096 & $<.001$ & .094 & $<.001$ & .086 & $<.001$ & .087 & $<.001$ \\
\hline Ever received FSM & & & & & & & & & & & & & & \\
\hline$(1=Y)$ & & & & & & & .052 & .003 & .059 & .001 & .056 & .001 & .056 & .001 \\
\hline Y7: Liking for school & & & & & & & & & .149 & $<.001$ & & & .040 & .031 \\
\hline Y7: General self- & & & & & & & & & & & & & & \\
\hline confidence & & & & & & & & & & & .238 & $<.001$ & .217 & $<.001$ \\
\hline Explained variance & $2.6 \%$ & & $4.0 \%$ & & $4.2 \%$ & & $16.0 \%$ & & $18.0 \%$ & & $20.8 \%$ & & $21.1 \%$ & \\
\hline $\begin{array}{l}\text { Unexplained variance } \\
\text { (residual) }\end{array}$ & $92.3 \%$ & & $91.3 \%$ & & $91.2 \%$ & & $82.4 \%$ & & $80.3 \%$ & & $78.0 \%$ & & $77.7 \%$ & \\
\hline
\end{tabular}


Unexplained variance

(school)

$5.1 \%$

$4.6 \%$

$4.6 \%$

$1.6 \%$

$1.8 \%$

$1.1 \%$

$1.2 \%$

Notes: Standardised coefficients (Std. B) and significance (Sig (p); p-values) are shown; ethnicity categories reflect comparisons against White students; significant coefficients and $\mathrm{p}$-values $(\mathrm{p}<.05)$ are highlighted in bold

Table 4 - Predicting students' university aspirations (reported as of Year 7) by sets in English

\begin{tabular}{|c|c|c|c|c|c|c|c|c|c|c|c|c|c|c|}
\hline \multirow[b]{2}{*}{ Predictor } & \multicolumn{2}{|c|}{ Step 1a } & \multicolumn{2}{|c|}{ Step $1 b$} & \multicolumn{2}{|c|}{ Step 2} & \multicolumn{2}{|c|}{ Step 3} & \multicolumn{2}{|c|}{ Step 4a } & \multicolumn{2}{|c|}{ Step $4 b$} & \multicolumn{2}{|c|}{ Step 5} \\
\hline & Std. B & $\begin{array}{l}\text { Sig } \\
\text { (p) }\end{array}$ & Std. B & $\begin{array}{l}\text { Sig } \\
\text { (p) }\end{array}$ & Std. B & $\begin{array}{l}\text { Sig } \\
\text { (p) }\end{array}$ & Std. B & $\begin{array}{l}\text { Sig } \\
\text { (p) }\end{array}$ & Std. B & $\begin{array}{l}\text { Sig } \\
\text { (p) }\end{array}$ & Std. B & $\begin{array}{l}\text { Sig } \\
\text { (p) }\end{array}$ & Std. B & $\begin{array}{l}\text { Sig } \\
\text { (p) }\end{array}$ \\
\hline Constant/intercept & N/A & $<.001$ & N/A & $<.001$ & N/A & $<.001$ & N/A & $<.001$ & N/A & $<.001$ & N/A & .002 & N/A & .005 \\
\hline $\begin{array}{l}\text { Y7: Setting: Middle set } \\
\text { (v. top) }\end{array}$ & -.131 & $<.001$ & & & -.074 & .009 & -.069 & .013 & -.064 & .020 & -.036 & .175 & -.038 & .163 \\
\hline $\begin{array}{l}\text { Y7: Setting: Bottom set } \\
\text { (v. top) }\end{array}$ & -.114 & $<.001$ & & & -.063 & .024 & -.063 & .026 & -.057 & .040 & -.044 & .106 & -.044 & 106 \\
\hline KS2 reading fine score & & & .174 & $<.001$ & .125 & $<.001$ & .103 & .001 & .106 & .001 & .080 & .008 & .081 & .008 \\
\hline Gender (1=boy) & & & & & & & -.068 & .005 & -.060 & .013 & -.080 & .001 & -.079 & .001 \\
\hline Ethnicity: Asian $(1=Y)$ & & & & & & & .116 & $<.001$ & .107 & $<.001$ & .104 & $<.001$ & .104 & $<.001$ \\
\hline Ethnicity: Black (1=Y) & & & & & & & .083 & .001 & .084 & .001 & .076 & .001 & .077 & .001 \\
\hline Ethnicity: Mixed (1=Y) & & & & & & & .028 & .247 & .036 & .129 & .030 & .196 & .031 & .181 \\
\hline Ethnicity: Other $(1=\mathrm{Y})$ & & & & & & & .003 & .883 & .008 & .747 & -.006 & .785 & -.005 & .828 \\
\hline $\operatorname{EAL}(1=\mathrm{Y})$ & & & & & & & .086 & .001 & .092 & $<.001$ & .078 & .001 & .079 & .001 \\
\hline Books at home & & & & & & & .051 & .056 & .028 & .294 & .020 & .442 & .021 & .430 \\
\hline Highest parental & & & & & & & & & & & & & & \\
\hline education & & & & & & & .181 & $<.001$ & .190 & $<.001$ & .183 & $<.001$ & .184 & $<.001$ \\
\hline Highest parental & & & & & & & & & & & & & & \\
\hline $\begin{array}{l}\text { occupation } \\
\text { Ever received FSM }\end{array}$ & & & & & & & 3 & 1 & 6 & 1 & 2 & .001 & 3 & .001 \\
\hline$(1=\mathrm{Y})$ & & & & & & & .055 & .036 & .058 & .026 & .046 & .073 & .045 & .078 \\
\hline Y7: Liking for school & & & & & & & & & .140 & $<.001$ & & & .010 & .725 \\
\hline
\end{tabular}


Y7: General self-

confidence

\section{Explained variance}

$1.8 \%$

$2.5 \%$

$2.8 \%$

$14.3 \%$

.239

$<.001$

Unexplained variance

(residual)

$94.3 \%$

$93.9 \%$

$93.5 \%$

$85.7 \%$

$16.1 \%$

$19.1 \%$

.231

$<.001$

Unexplained variance

(school)

$3.9 \%$

$3.6 \%$

$3.7 \%$

$.1 \%$

$83.8 \%$

$80.9 \%$

$80.9 \%$

Notes: Standardised coefficients (Std. B) and significance (Sig (p); p-values) are shown; ethnicity categories reflect comparisons against White students; significant coefficients and $p$-values $(p<.05)$ are highlighted in bold 
about here

This modelling of data across both mathematics and English sets suggests that prior attainment, student characteristics (specifically gender, ethnicity, EAL status and parental occupation), cultural capital (parental education) and students' general self-confidence in learning consistently predict students' university aspirations. Our finding that boys are less likely to report to have university aspirations replicates findings from earlier studies (Berrington, Roberts and Tammes, 2016; Gale and Parker, 2015; Hartas, 2016). Another of our findings relating to student characteristics, that groups of students self-reporting their ethnicity as Asian, Black or Mixed were more likely to report to have university aspirations compared against students self-reporting their ethnicity as White reflects trends in UCAS applications in the UK discussed by Whitty, Hayton and Tang (2015). In our modelling EAL status increased the likelihood of students' university aspirations, however there was only a relatively small number of students with EAL status in our dataset for the present analysis. Nevertheless, Bowden and Doughney (2010) also similarly found that students who do not speak English at home were more likely to aspire to university. In relation to measures of students' socio-economic status, our finding of a positive relationship between the level of parental occupation and students' university aspirations is also in line with prior research suggesting that socio-economic background influences students' university aspirations with students from less privileged backgrounds less likely to apply to university (Anders 2017; Tomaszewski, Perales and Xiang, 2017).

Cultural capital measured through parental education was predictive of university aspirations in our data, with the level of parental education positively correlating with university aspirations. This is a similar finding to Davies, Qiu and Davies' (2014) study which importantly also identified that factors relating to cultural capital had a greater impact in the case of students with average rather than high grade expectations. All else being equal, students with average levels of prior attainment but from home environments with more cultural capital are thus more likely to have university aspirations in comparison with students from home environments with less cultural capital. Measuring cultural capital through the variable of number of books at home emerged as a predictor from the data of sets in mathematics (Table 3), but not for English (Table 4). 
Turning to the longitudinal data on students' university aspirations (Tables 5 and 6) we find that unsurprisingly the key predictor of student aspirations in Year 8 are student aspirations in Year 7. The modelling suggests that over and above this key predictor of Year 7 aspirations, there is still a statistically significant relationship between prior attainment, gender, student self-reported ethnicity, EAL and FSM status, books at home, highest parental occupation, liking for school and general self-confidence in learning in Year 8. These statistically significant relationships hold whether we use set placement in Year 8 (see Model C in Tables $5 \&$ 6) or in Year 7 (see Model D in Tables 5 \& 6). Student aspirations in Year 7 are however clearly the strongest predictors. Of the remaining variables, the association between student aspirations and student general self-confidence in learning is of the highest magnitude.

There are however intriguing differences in our findings depending on whether we use set placement in Year 7 or Year 8. When we model based on the latest data (Year 8), set placement does appear to influence aspirations at Year 8, and students placed in top sets appear to have higher aspirations over and above the effects of prior attainment and aspirations in Year 7 (see Model $\mathrm{C}$ in Tables 5 \& 6). The associated magnitudes are slight, but these findings clearly differ from modelling based on initial set placement data (see Model D in Tables 5 \& 6) which shows no statistically significant relationship between students' university aspirations and their set placement.

Table 5 - Predicting students' university aspirations (reported as of Year 8) by sets in mathematics

Table 6 - Predicting students' university aspirations (reported as of Year 8) by sets in English about here 
Table 5 - Predicting students' university aspirations (reported as of Year 8) by sets in mathematics

\begin{tabular}{|c|c|c|c|c|c|c|c|c|}
\hline \multirow[b]{2}{*}{ Predictor } & \multicolumn{2}{|c|}{ Model A } & \multicolumn{2}{|c|}{ Model B } & \multicolumn{2}{|c|}{ Model C } & \multicolumn{2}{|c|}{ Model D } \\
\hline & Std. B & $\operatorname{Sig}(\mathrm{p})$ & Std. B & $\operatorname{Sig}(p)$ & Std. B & $\operatorname{Sig}(p)$ & Std. B & $\operatorname{Sig}(p)$ \\
\hline Constant/intercept & $\mathbf{N} / \mathbf{A}$ & $<.001$ & N/A & $<.001$ & N/A & .002 & N/A & .325 \\
\hline Y7: University aspirations & & & & & .400 & $<.001$ & .401 & $<.001$ \\
\hline Y7: Setting: Middle set (v. top) & & & & & & & $<.001$ & .992 \\
\hline Y7: Setting: Bottom set (v. top) & & & & & & & .005 & .783 \\
\hline Y8: Setting: Middle set (v. top) & -.073 & $<.001$ & -.073 & $<.001$ & -.056 & .003 & & \\
\hline Y8: Setting: Bottom set (v. top) & -.052 & .007 & -.052 & .008 & -.056 & .002 & & \\
\hline KS2 Mathematics fine score & .085 & $<.001$ & .082 & $<.001$ & .052 & .014 & .101 & $<.001$ \\
\hline Gender (1=boy) & -.119 & $<.001$ & -.117 & $<.001$ & -.082 & $<.001$ & -.081 & $<.001$ \\
\hline Ethnicity: Asian $(1=\mathrm{Y})$ & .098 & $<.001$ & .098 & $<.001$ & .055 & $<.001$ & .059 & $<.001$ \\
\hline Ethnicity: Black $(1=\mathrm{Y})$ & .111 & $<.001$ & .111 & $<.001$ & .084 & $<.001$ & .089 & $<.001$ \\
\hline Ethnicity: Mixed (1=Y) & .053 & $<.001$ & .052 & $<.001$ & .035 & .012 & .034 & .010 \\
\hline Ethnicity: Other $(1=\mathrm{Y})$ & .046 & .004 & .045 & .006 & .025 & .098 & .030 & .037 \\
\hline $\operatorname{EAL}(1=\mathrm{Y})$ & .080 & $<.001$ & .079 & $<.001$ & .059 & $<.001$ & .058 & $<.001$ \\
\hline Books at home & .083 & $<.001$ & .079 & $<.001$ & .066 & $<.001$ & .065 & $<.001$ \\
\hline Highest parental education & .095 & $<.001$ & .095 & $<.001$ & .034 & .032 & .025 & .108 \\
\hline Highest parental occupation & .077 & $<.001$ & .076 & $<.001$ & .042 & .007 & .047 & .002 \\
\hline Ever received FSM $(1=Y)$ & .059 & .001 & .059 & .001 & .040 & .013 & .049 & .001 \\
\hline Y7: Liking for school & & & .016 & .431 & -.012 & .507 & -.018 & .325 \\
\hline Y8: Liking for school & .055 & .005 & .048 & .024 & .075 & $<.001$ & .073 & $<.001$ \\
\hline Y7: General self-confidence & & & .028 & .175 & -.054 & .007 & -.051 & .007 \\
\hline Y8: General self-confidence & .232 & $<.001$ & .220 & $<.001$ & .192 & $<.001$ & .212 & $<.001$ \\
\hline Explained variance & $26.3 \%$ & & $26.3 \%$ & & $40.6 \%$ & & $39.3 \%$ & \\
\hline Unexplained variance (residual) & $72.8 \%$ & & $72.7 \%$ & & $59.0 \%$ & & $60.2 \%$ & \\
\hline Unexplained variance (school) & $.9 \%$ & & $1.0 \%$ & & $.4 \%$ & & $.5 \%$ & \\
\hline
\end{tabular}

Notes: Standardised coefficients (Std. B) and significance (Sig (p); p-values) are shown; ethnicity categories reflect comparisons against White students; significant coefficients and $\mathrm{p}$-values $(\mathrm{p}<.05)$ are highlighted in bold 
Table 6 - Predicting students' university aspirations (reported as of Year 8) by sets in English

\begin{tabular}{|c|c|c|c|c|c|c|c|c|}
\hline \multirow[b]{2}{*}{ Predictor } & \multicolumn{2}{|c|}{ Model A } & \multicolumn{2}{|c|}{ Model B } & \multicolumn{2}{|c|}{ Model C } & \multicolumn{2}{|c|}{ Model D } \\
\hline & Std. B & $\operatorname{Sig}(p)$ & Std. B & $\operatorname{Sig}(p)$ & Std. B & $\operatorname{Sig}(p)$ & Std. B & $\operatorname{Sig}(p)$ \\
\hline Constant/intercept & N/A & .040 & $\mathrm{~N} / \mathrm{A}$ & .070 & N/A & .472 & N/A & .711 \\
\hline Y7: University aspirations & & & & & .400 & $<.001$ & .396 & $<.001$ \\
\hline Y7: Setting: Middle set (v. top) & & & & & & & .001 & .961 \\
\hline Y7: Setting: Bottom set (v. top) & & & & & & & -.023 & .365 \\
\hline Y8: Setting: Middle set (v. top) & -.070 & .011 & -.069 & .013 & -.056 & .038 & & \\
\hline Y8: Setting: Bottom set (v. top) & -.053 & .074 & -.052 & .080 & -.043 & .143 & & \\
\hline $\mathrm{KS} 2$ reading fine score & .171 & $<.001$ & .168 & $<.001$ & .130 & $<.001$ & .137 & $<.001$ \\
\hline Gender (1=boy) & -.120 & $<.001$ & -.123 & $<.001$ & -.084 & $<.001$ & -.077 & $<.001$ \\
\hline Ethnicity: Asian $(1=\mathrm{Y})$ & .096 & $<.001$ & .097 & $<.001$ & .056 & .022 & .035 & .105 \\
\hline Ethnicity: Black $(1=\mathrm{Y})$ & .098 & $<.001$ & .097 & $<.001$ & .075 & .001 & .068 & .001 \\
\hline Ethnicity: Mixed (1=Y) & .023 & .337 & .023 & .350 & .012 & .586 & .010 & .650 \\
\hline Ethnicity: Other $(1=\mathrm{Y})$ & .047 & .059 & .045 & .070 & .038 & .096 & .024 & .258 \\
\hline $\operatorname{EAL}(1=\mathrm{Y})$ & .120 & $<.001$ & .119 & $<.001$ & .081 & .001 & .090 & $<.001$ \\
\hline Books at home & .041 & .124 & .043 & .110 & .065 & .013 & .071 & .003 \\
\hline Highest parental education & .059 & .023 & .059 & .025 & -.025 & .321 & -.019 & .418 \\
\hline Highest parental occupation & .113 & $<.001$ & .114 & $<.001$ & .092 & $<.001$ & .086 & $<.001$ \\
\hline Ever received FSM $(1=\mathrm{Y})$ & .065 & .013 & .061 & .022 & .051 & .046 & .056 & .015 \\
\hline Y7: Liking for school & & & -.031 & .343 & -.056 & .077 & -.028 & .324 \\
\hline Y8: Liking for school & .050 & .100 & .060 & .063 & .082 & .010 & .063 & .027 \\
\hline Y7: General self-confidence & & & .037 & .269 & -.038 & .244 & -.044 & .139 \\
\hline Y8: General self-confidence & .206 & $<.001$ & .191 & $<.001$ & .163 & $<.001$ & .198 & $<.001$ \\
\hline Explained variance & $24.2 \%$ & & $24.3 \%$ & & $37.2 \%$ & & $37.4 \%$ & \\
\hline Unexplained variance (residual) & $75.4 \%$ & & $75.3 \%$ & & $62.4 \%$ & & $62.1 \%$ & \\
\hline Unexplained variance (school) & $.4 \%$ & & $.4 \%$ & & $.4 \%$ & & $.5 \%$ & \\
\hline
\end{tabular}

Notes: Standardised coefficients (Std. B) and significance (Sig (p); p-values) are shown; ethnicity categories reflect comparisons against White students; significant coefficients and $\mathrm{p}$-values $(\mathrm{p}<.05)$ are highlighted in bold 
In addition to the interesting findings on the impact of set placement on students' university aspirations, an important and novel finding from our study is that self-confidence predicts university aspirations over and above both prior aspirations and attainment. Students' general self-confidence in learning emerged as the strongest predictor for university aspirations across the students participating in the study aside from aspirations at Year 7. Elsewhere (Francis et al., 2017b) we have reported the finding from the wider study of an association between students' subject self-confidence and their set level that extends to students' general selfconfidence.

\section{Discussion}

Prior research suggests that grouping practices could impact on students' university aspirations via a differentiated curriculum accessed by students in the different groups, and the labelling communicated by the practice of tracking/setting. (Berends, 1995; Gillborn and Youdell, 2000; Lehmann, 2009; Venezia and Kirst, 2005). Our findings from a two-year study suggest that there is a slight cumulative association between secondary school students' university aspirations and their set placement (top, middle or bottom). Modelling based on initial student set placement data suggests that there is no relationship between students' university aspirations and their set placement when controlling for variables identified in prior research as impacting on university aspirations (prior attainment, student characteristics, cultural capital) and variables measuring aspects of student experiences or attitudes at school (student liking for school and general self-confidence in learning). Modelling based on final student set placement data however suggests that there is a slight association between students' set placement and their university aspirations. By the second year of setting in secondary school, placement in a top set appears to positively impact on students' university aspirations over and above the effects of prior attainment and aspirations.

Our findings suggest that universities stand to gain from a greater understanding of students' educational trajectories and experiences at secondary school if they are to increase the number of students from more disadvantaged backgrounds entering university. The significance of selfconfidence in predicting students' university aspirations is a novel and important finding. Over the study period, all else being equal, it was students scoring their general self-confidence in learning relatively higher, that were most likely to positively change their aspirations aged 12- 
13 from those reported in the previous academic year. We can interpret self-confidence as being one manifestation or a facet of the capacity to aspire. It is also important to note that selfconfidence is a considerably stronger predictor of students' university aspirations than prior attainment. Our findings thus suggest that in order to enhance our understanding of students' university aspirations and their development, we need to take account of factors other than just prior attainment, especially as the causal relationships between student aspirations and attainment remain unclear (Gorard, See and Davies, 2012).

The concept of the capacity to aspire is helpful in developing our understanding as it emphasises the multiplicity of factors involved in enabling or hindering an individual's aspiration for university, and their interaction over time. Returning to Kintrea, St Clair and Houston's (2011) example of a young person wanting to become a lawyer, if we think of the different cumulative steps that are typically involved in entering such a profession, individual aspiration on its own is clearly insufficient to realise this aspiration if the young person leaves school at the age of 16. Knowledge and understanding of the different steps required well in advance in order to exert active agency rather than drifting into learning pathways incompatible with the future aspiration can for example make the difference between a student who realises his/her aspiration and a student who self-moderates his/her aspiration over time (Campbell and McKendrick, 2017). The role of the family and the school environment in providing knowledge and understanding of the steps required to realise an aspiration is thus crucial, and critical in enhancing or diminishing a young person's capacity to aspire. This may be particularly important with regards to students from low socio-economic backgrounds who have been found to be more likely to change their minds about university aspirations between the ages of 14 and 17 (Anders, 2017). Prior longitudinal research on aspirations (Kintrea, St Clair and Houston, 2011; Tomaszewski, Perales and Xiang, 2017) has suggested that these groups of students would particularly benefit from guidance and support in the practical steps in turning their aspirations to a reality through for example good and ongoing careers advice and access to work experience.

As the data we have presented here is part of a larger study, our analysis remains limited by the constraints of the original study with, for example only one student questionnaire item focusing on students' university aspirations. It is also important to note that the questionnaire item was worded in terms of students' expectations, whilst expectations and aspirations can be conceptualised as distinct phenomena (Anders, 2017). All students with university aspirations 
in our sample might thus not have not responded tentatively or affirmatively as expecting to go to university.

Whilst we have shown that students' capacity to aspire to university is likely to be influenced by a combination of factors including students' home environment, we would like to conclude by reiterating the importance of schools, careers advice and universities in achieving more socially just higher education participation outcomes. Our findings suggest that the level of aspiration for university is high amongst young people yet relatively fewer students from disadvantaged backgrounds pursue higher education suggesting that there are structural issues at play that may further hinder students' capacity to aspire to university past our measurement points of ages 11-13. There is thus a clear role for schools and careers advice in developing students' capacity to aspire, but also a role for the higher education sector. Whilst there are great examples of universities engaging in outreach work with secondary school students, the higher education sector in the UK and internationally should consider more carefully the opportunity to challenge the socially unjust patterns in university participation through ongoing outreach activity in schools and communities that can support disadvantaged young people in enhancing their capacity to aspire to university. 


\section{References}

Altbach,P., Reisberg, L. \& Rumbley, L. (2009). Trends in global higher education. Tracking an academic revolution. Paris: Unesco.

Anders, J. (2012). The link between household income, university applications and university attendance. Fiscal Studies, 33, 185-210.

Anders, J. (2017). The influence of socioeconomic status on changes in young people's expectations of applying to university. Oxford Review of Education, 43 (4), 381-401.

Appadurai, A. (2004). The capacity to aspire: culture and terms of recognition. In R. Vijayendra and M. Walton (Eds.) Culture and Public Action (pp. 59-84). Stanford: Stanford University Press.

Archer, L., Hollingworth, S. \& Halsall, A. (2007). University's not for Me-I'm a Nike Person': Urban, Working-Class Young People's Negotiations of Style', Identity and Educational Engagement. Sociology 41 (2), 219-237.

Archer, L., DeWitt, J. \& Wong, B. (2014). Spheres of influence: what shapes young people's aspirations at age 12/13 and what are the implications for education policy? Journal of Education Policy, 29 (1), 58-85.

Ball, S. (2010). New class inequalities in education: Why education policy may be looking in the wrong place! Education, civil society and social class. International Journal of Sociology and Social Policy 30 (3/4), 155-166.

Ball, S., Davies, J., David, M. \& Reay, D. (2002). 'Classification' and 'judgement': Social class and the 'cognitive structures' of choice of higher education. British Journal of Sociology of Education, 23 (1), 51-72.

Berends, M. (1995). Educational Stratification and Students' Social Bonding to School, British Journal of Sociology of Education, 16 (3), 327-351.

Berrington, A., Roberts, S. \& Tammes, P. (2016). Educational aspirations among UK Young Teenagers: Exploring the role of gender, class and ethnicity. British Educational Research Journal, 42 (5), 729-755.

Boaler, J., Wiliam, D. \& Brown, M. (2000). Students' experiences of ability grouping disaffection, polarisation and the construction of failure. British Educational Research Journal, 26 (5), 631-48.

Bok, J. (2010). The capacity to aspire to higher education: 'It's like making them do a play without a script.' Critical Studies in Education, 51 (2), 163-178.

Bowden, M. \& Doughney, J. (2010). Socio-economic status, cultural diversity and the aspirations of secondary students in the Western Suburbs of Melbourne, Australia. Higher Education 59, 115-129. 
Campbell, L. \& McKendrick, J. (2017). Beyond aspiration: deploying the capability approach to tackle the under-representation in higher education of young people from deprived communities, Studies in Continuing Education, 39 (2), 120-137.

Chowdry, H., Crawford, C., Dearden, L., Goodman, A. \& Vignoles, A. (2010). Widening participation in higher education: Analysis using linked administrative data. London: Institute for Fiscal Studies.

Dalby, D. \& Noyes, Andrew. (2016). Locating mathematics within post-16 vocational education in England, Journal of Vocational Education and Training, 68 (1), 70-86.

Davies, P. (2012). Can Governments Improve Higher Education Through 'Informing Choice'? British Journal of Education Studies 60 (3), 261-276.

Davies, P., Qiu, T. \& Davies, N. (2014). Cultural and human capital, information and higher education choices, Journal of Education Policy, 29 (6), 804-825.

Dunne, M., Humphreys, S., Sebba, J., Dyson, A., Gallannaugh, F., \& Muijs, D. (2007). Effective teaching and learning for pupils in low attaining groups. London: DCSF.

Francis, B., Archer, L., Hodgen, J., Pepper, D., Taylor, B. \& Travers, M-C. (2017a). Exploring the relative lack of impact of research on 'ability grouping' in England: a discourse analytic account. Cambridge Journal of Education, 1-17.

Francis, B., Connelly, P., Archer, L., Hodgen, J., Mazenod, A., Taylor, B., Tereshchenko, A. \& Pepper, D. (2017b). Attainment grouping as self-fulfilling prophesy? A mixed methods exploration of self-confidence and set level among year 7 students. International Journal of Educational Research. 86: 96-108.

Furlong, A. (2005). Cultural dimensions of decisions about educational participation among 14-19 - year-olds: the parts that Tomlinson doesn't reach, Journal of Education Policy, 20 (3), 379-389.

Gale, T. \& Parker, S. (2013). Calculating student aspiration: Bourdieu, spatiality and the politics of recognition. Cambridge Journal of Education, 45 (1), 81-96.

Gillborn, D. \& Youdell, D. (2000). Rationing education: Policy, practice, reform and equity. Buckingham: Open University Press.

Gorard, S., See, B., \& Davies, P. (2012). The impact of attitudes and aspirations on educational attainment and participation. York: Joseph Rowntree.

Hart, S., Dixon, A., Drummond, M. \& McIntyre, D. (2004). Learning without limits. Maidenhead: Open University Press.

Hartas, D. (2016). Young people's educational aspirations: psychosocial factors and the home environment, Journal of Youth Studies, 19 (9), 1145-1163.

Kintrea, K., St Clair, R. \& Houston, M. (2011). The influence of parents, places and poverty on educational attitudes and aspirations. Joseph Rowntree Foundation. 
https://www.jrf.org.uk/sites/default/files/jrf/migrated/files/young-people-education-attitudesfull.pdf Accessed 10 May 2018.

Kutnick, P., Sebba, J., Blatchford, P., Galton, M., Thorp, J., MacIntyre, H. \& Berdondini, L. (2005). The Effects of Pupil Grouping: Literature Review. London: DfES.

Lehmann, W. (2009). University as vocational education: working-class students' expectations for university, British Journal of Sociology of Education.30 (2), 137-149.

Mangan, J., Hughes, A., Davies, P. \& Slack, K. (2010). Fair access, achievement and geography: explaining the association between social class and students' choice of university, Studies in Higher Education, 35 (3), 335-350.

Mazenod, A., Miller, S., Francis B., Archer L., Hodgen, J., Taylor, B. \& Tereshchenko, A. forthcoming. Liking, loving or loathing? Attainment grouping and student liking for school

McMahon, S., Harwood, V. \& Hickey-Moody, A. (2016). 'Students that just hate school wouldn't go': Educationally disengaged and disadvantaged young people's talk about university education. British Journal of Sociology of Education, 37 (8), 1109-1128.

Noble, J. \& Davies, P. (2009). Cultural capital as an explanation of variation in participation in higher education, British Journal of Sociology of Education, 30 (5), 591-605.

Oakes, J. (1985). Keeping track: How schools structure inequality. $2^{\text {nd }}$ edn. New Haven, CT: Yale University Press.

OECD. (2013). PISA 2012 results: What makes schools successful? Resources, policies and practices (Volume IV), PISA, OECD Publishing. https://www.oecd.org/pisa/keyfindings/pisa2012-results-volume-IV.pdf Accessed 1 March 2018.

Parsons, S. \& Hallam, I. (2014). The impact of streaming on attainment at age seven: evidence from the Millennium Cohort Study. Oxford Review of Education, 40 (5), 567-589.

Perna, L. \& Titus, M. (2005). The relationship between parental involvement as social capital and college enrollment: an examination of racial/ethnic group differences. Retrieved from $h$ p://repository.upenn.edu/gse_pubs/14

Santelices, M., Horn, C. \& Catalán, X. (2017). Institution-level admissions initiatives in Chile: enhancing equity in higher education? Studies in Higher Education, DOI: 10.1080/03075079.2017.1398722

Smith, L. (2011). Experiential 'hot' knowledge and its influence on low-SES students' capacities to aspire to higher education. Critical Studies in Education, 52 (2), 165-177.

Snijders, T. \& Bosker, R. (2012). Multilevel Analysis: An Introduction to Basic and Advanced Multilevel Modeling (2nd ed.). London: SAGE Publications.

Taylor, B., Francis, B., Archer, L., Hodgen, J., Pepper, D., Tereshchenko, A. \& Travers, M-C. (2016). Factors deterring schools from mixed attainment teaching practice. Pedagogy, Culture \& Society. 25 (3), 327-345. 
Taylor, B., Francis, B., Craig, N., Archer, L., Hodgen, J., Mazenod, A., Tereshchenko, A. \& Pepper, D. (2018). Why is it difficult for schools to establish equitable practices in allocating students to attainment 'sets'? British Journal of Educational Studies, doi:

$\underline{10.1080 / 00071005.2018 .1424317}$

Tomaszwewski, W., Perales, F. \& Xiang, N. (2017). Career guidance, school experiences and the university participation of young people from low socio-economic backgrounds.

International Journal of Educational Research, 85, 11-23.

Venezia, A. \& Kirst, M. (2005). Inequitable opportunities: how current education systems and policies undermine the chances for student persistence and success in college.

Educational Policy, 19 (2), 283-307. https://doi.org/10.1177/0895904804274054

Whitty, G., Hayton, A. \& Tang, S. (2015). Who you know, what you know and knowing the ropes: a review of evidence about access to higher education institutions in England. Review of Education, 3 (1), 27-67.

Zipin, L., Sellar, S., Brennan, M. \& Gale, T. (2015). Educating for futures in marginalized regions: A sociological framework for rethinking and researching aspirations. Educational Philosophy and Theory, 47 (3), 227-246. 